\title{
DEMOCRACY AND HUMAN RIGHTS IN THE EUROPEAN COURT OF HUMAN RIGHTS: A CRITICAL APPRAISAL
}

In a recent valuable article, Alistair Mowbray has traced the way in which the European Court of Human Rights has interpreted the European Convention on Human Rights so as to facilitate the promotion of democracy. ${ }^{1}$ His inquiry leads him to the conclusion that "in contemporary times the court has generally developed and applied its concept of democracy in a progressive manner which has sought to enhance and safeguard the vitality of the political process operating in Member States". ${ }^{2}$ Mowbray's starting point in the building of an empirical basis for this conclusion is United Communist Party of Turkey v Turkey. ${ }^{3}$ In that case, the Court identified "a number of links between Convention rights and duties and the idea of democracy." These were "apparent, first, from the Preamble to the Convention, which establishes a very clear connection between the Convention and democracy by stating that the maintenance and further realisation of human rights and fundamental freedoms are best ensured on the one hand by an effective political democracy and on the other by a common understanding and observance of human rights." 5 The second relevant link lay in the "necessary in a democratic society" proviso to be found to the rights set out in Articles 8, 9, 10 and 11 of the Convention, which in Mowbray's view served in combination to demonstrate that "the framers expressly incorporated the idea of democracy into the text of the Convention and gave it a prominent role in the balancing of individual claims against the needs of the community as a whole." 6

As his third example of the linkage identified in United Communist Party, Mowbray points out that the Court has frequently drawn attention to certain of the Convention provisions, such as the guarantee of free elections ${ }^{7}$ and freedom of expression, ${ }^{8}$ as underpinning its recognition of "significant interconnections between the aims and substance of the Convention, and democracy within Member States." 9 Finally Mowbray notes that on many occasions the Court has declared "pluralism to be at the heart of its conception of democracy"10 and has insisted upon such pluralism in its interpretation of Convention rights. To Mowbray these

1 "The Role of the European Court of Human Rights in the Promotion of Democracy" [1999] PL 703.

2 Ibid p 725. See also Marks, "The European Convention on Human Rights and its 'Democratic Society"“ (1995) 66British Yearbook of International Law 209.

3 (1998) 26 EHRR 121.

${ }^{4}$ Op cit $\mathrm{n} 1$ at $\mathrm{p} 703$.

5 Op cit $\mathrm{n} 3$ at para 45 .

${ }^{6}$ Op cit $\mathrm{n} 1$ at $\mathrm{p} 703$.

7 Article 3 of Protocol No 1.

8 Article 10

9 Op cit $\mathrm{n} 1$ at $\mathrm{p} 704$.

${ }^{10} \mathrm{Ibid}$, citing United Communist Party of Turkey v Turkey, op cit $\mathrm{n} 3$ at para 43. 
various linkages make apparent that "the court equates democracy with societies where there is a vigorous public debate about matters of public policy and constitutional arrangements conducted by the public themselves and through their representatives in the forms of political parties and elected politicians" and that furthermore "[n]ational governments are under Convention duties to safeguard these components of democracy by, inter alia, facilitating diversity in the media, respecting protected forms of free expression, permitting the existence of political parties which subscribe to democratic values and holding free elections." 11

There is much that is true here and much in the Court's record that is to be applauded. The efforts made by the Strasbourg bench to hew out of the open-ended texture of the European Convention a commitment to political participation and to civil liberties have not been negligible. The case-law has regularly sought to locate itself in a series of principles which have distinguished issues of concern to democratic systems and to civil liberties and to prioritise these matters over other human rights considerations; Mowbray is therefore right to give credit where credit is due. ${ }^{12}$ It is also entirely understandable why the Court should so consistently have sought to present its engagement with these issues in the language of "democracy" as well as in that of "the rule of law" and "human rights": its members are the interpreters of a particular text whose discourse requires that its judicial interventions should be so phrased. While not undermining the thrust of this jurisprudence, so comprehensively analysed by Mowbray, it is perhaps appropriate in the course of this essay to enter here just a few complicating caveats. Things are not always exactly as they seem; even apparently straightforward assertions can hide more than those making such claims appreciate. This is particularly the case in the juristic world inhabited by the language of "democracy" and "human rights", words as morally pure as they are rife with ambiguity. The caveats to Mowbray's vision that will be considered here are three in number.

\section{The Court and the Member States}

The first relates to the institutional limitations inherent in the judicial role. The Court's impressive dicta on democracy and human rights and its confident assertions about the kind of Europe that it will accept might mislead some into the belief that here is a very powerful European body, with the capacity profoundly to affect European perceptions of democracy, the rule of law and diversity. This may be true in the very long term. It may also be true in the sense that the Strasbourg tribunal probably does have an indirect influence over the development of legal principles in its Member States. It certain impacts sharply on the legal communities of many of the Member States, but then again it would be surprising if it did not. In terms of immediate power, of the capacity to execute its will,

11 Ibid at pp 705-6 (footnotes omitted).

12 The article, op cit $\mathrm{n} 1$, provides a comprehensive survey of the case-law which will not be repeated here. For earlier reflections on the same topic see Gearty, "The European Court of Human Rights and the Protection of Civil Liberties: An Overview" (1993) 52 CLJ 89 at pp 115-25. 
however, such rhetoric masks the degree to which the Court is a very weak body indeed. The judicial limb to any constitutional system may be "the least dangerous branch"13 of government, but this is also because it is the least effective, with no police force to call its own, no capacity directly to implement its decisions and no policy arm to formulate (much less to apply) general rules. What is true of every court is even truer of the European Court which must rely on the executive officers not of its own nation (it doesn't have one) but of those of individual Member States: a double remoteness from the reality of its own rulings. ${ }^{14}$ More critically from the perspective of the European Court is the fact that courts are by their nature reactive and ex post facto in their adjudications. They depend on others to initiate disputes and then rely on a whole series of extraneous decisions by independent actors before they can find themselves seised of an issue of principle. This then occurs long after - perhaps years after - the events to which they gave rise. Even if the execution of their judgments were entirely within their control, whatever the courts say in such circumstances will often be simply irrelevant to the contemporary situation in the place from which the case came. The converse truth is that whatever it says will often be too late to impact on the situation to which it is retrospectively (one could almost say hypothetically) giving its attention.

All of this is obvious, banal even: everyone knows that courts are neither legislatures nor executive bodies, so it is pointless to criticise them for not being what they never set out to be in the first place. This is surely almost always a valid point. The difficulty lies in the language. Lawyers are educated to take seriously the dicta of judges. The more high flown such rhetoric (and the deployment of "human rights" in a legal discourse is as high as it gets) the easier it is to forget the institutional limitations that surround the body from which such pleasing language is flowing. But the more these circumscriptions are forgotten, the more tempting it becomes to take at face value judicial assertions of principle, treating them as reflective of a reality far larger and more pervasive than the passing wishes of a few men and women locked in an adversarial dispute in a courtroom. At its most serious, this drift from the larger reality can led to a bizarre dsyfunction, with judicial assertions of principle co-existing comfortably and without embarrassment with the most horrendous evidence that outside the courtroom these principles matter hardly at all. At this point the two worlds, the political and the judicial have drifted so completely apart that they do not even recognise that they each inhabit the same national air-space. We have seen dysfunctions of this nature in the past in authoritarian and totalitarian societies, with apparently morally valuable legal systems functioning side by side with the most awful tyranny. The point might be thought also to have arisen in the Council of Europe in relation to Russia, which became a Member State on 28

13 Bickel, The Least dangerous Branch: The Supreme Court at the Bar of Politics (1962)

14 See Parliamentary Assembly, Committee on Legal Affairs and Human Rights, Execution of Judgments of the European Court of Human Rights, Draft Report (AS Jur (2000) 39. 26 June 2000). 
February 1996, and where the Convention has been notionally available to be relied upon since ratification on 5 May 1998.

During these years, the Russian army has been engaged in a large-scale military action against Chechnya, conduct which has proved highly controversial and which has provoked intense international condemnation and debate, not least in the Council of Europe itself where the Assembly has condemned the action as a violation of the Convention and of international humanitarian law "as well as [of] Russia's commitments [which] she entered into upon accession to the Council of Europe". ${ }^{15}$ The Council's parliamentarians have demanded various responses from the Russian authorities and asked the Committee of Ministers to take measures to help achieve a peaceful settlement. ${ }^{16}$ Throughout this period, however, the institutional limitations inherent in the judicial process discussed above have reduced the European Court of Human Rights to silence. The very enormity of the crisis, the vastness of the violations of human rights in issue, have made the problem just too great to be addressed: "victims" were in no position to come forward; legal redress for wrongs done to individuals was low down on the agendas of the aid agencies involved in the region; the mechanisms of Convention enforcement were certain to be ineffective even if they could somehow be successfully wheeled into action. What progress that was made at the Council of Europe was made by other organs and authorities, such as the Commissioner for Human Rights ${ }^{17}$, who were able to act on their own initiative, to visit controversial war-zones and force an engagement with reluctant Russia officials. ${ }^{18}$

In contrast, the five cases that have found their way to Strasbourg from Russia during the same period (all unsuccessful) concerned fair procedures under Article $6,{ }^{19}$ the right to liberty in Article $5,{ }^{20}$ the validity of election procedures in Vladivostock ${ }^{21}$ and a delay in the payment of a pension. ${ }^{22}$ Nothing so far has come from the war region, or dealt with matters arising from the conflict there, and even if this were to happen now, it is not obvious what effect such a late assertion of human rights protection could possibly have. A harsh critic might conclude from the

15 Recommendation 1444 (27 January 2000) and Resolution 1201 (4 November 1999). See also the Declaration of the President of the Parliamentary Assembly on the executions in Chechnya, 12 March 1999: (1999) 46 Human Rights Information Bulletin 44; Parliamentary Assembly, Political Affairs Committee, The Conflict in Chechnya (Doc 8630. 25 January 2000).

16 Ibid. See further the reply from the Russian Federation to the Council of Europe's request under Article 52 of the European Convention on Human Rights, Parliamentary Assembly, Doc 8613 (17 January 2000).

17 Mr Alvaro Gil Robles.

18 The European Committee for the Prevention of Torture and Inhuman or Degrading Treatment or Punishment (CPT) visited the Chechen Republic at the end of February 2000 but was unable to enter certain districts of Grozny on account of fighting in those areas.

19 Tumilovich v Russia application 47033/99: inadmissible 22 June 1999; Lukach v Russia application 48041/99: inadmissible 16 November 1999.

20 Syrkin v Russia application 44125/98: inadmissible 25 November 1999.

21 Cherepkov v Russia application 51501/99: inadmissible 25 January 2000.

22 Taykov v Russia application 48498/99: struck off the lists 28 March 2000. 
extreme example of Russia that the Court's commitment to democracy and human rights is just hot air: frequently deployed (but probably unnecessary) in societies whose commitment to human rights and democracy is not in doubt; desperately necessary but never properly deployed in situations where such a commitment is urgently needed. This however would be unfair. The fact that so many cases at the Court in recent years have involved Turkey demonstrably undermines such a cynical assertion, and the results on the ground of the Strasbourg Court's engagement with Turkey may in time provide the definitive case-study on the effectiveness of a charter of human rights imposing itself through litigation in relatively hostile territory. ${ }^{23}$ For countries on the edge of democracy, committed in the abstract to representative government and human dignity, but hostile on the ground to the infilitration of such ideas, the Strasbourg Court may indeed play a vital role. Russia is however a warning against the complacency of rights talk in the judicial sphere, of succumbing to the lawyers' disease of believing that what judges say matters so very much. ${ }^{24}$

\section{The Court and democratic legitimacy}

Our second cautionary note with respect to the Court's jurisprudence arises in a situation which is the polar opposite of that in Chechyna but which is far more the norm in the Council of Europe, namely where a Member State enjoys a reasonably effective set of democratic institutions within its domestic constitutional arrangements, designed to resolve disagreement between various elements of its civil society. In this kind of politco-legal culture, a different kind of misguided certainty accompanies the way in which the Strasbourg judges deploy the language of democracy and human rights. We are not now talking about a dedication to "human rights" which has no connection with reality in a Member State, but rather one which imposes itself all too well, thanks to the commitment invariably to be found in such properly functioning Member States to the implementation of such judgments, as a matter of either national or international obligation. It may be obvious, despite which it remains puzzling, that the European Court of Human Rights can trump any national (democratic) dialogue with a conclusive intervention rooted in what the Convention is interpreted by these self-same Strasbourg judges to demand and that such verdicts are then not permitted to be objected to by

23 See in particular the Court's action in the Öcalan case, requesting as an interim measure under rule 39.1 that Turkey not carry out its death penalty against the applicant until the Strasbourg authorities have had an opportunity to consider his complaints. See generally Altiparmak, "Turkish Cases Relating to Terrorism Before the European Court of Human Rights: Procedural Issues" (2000) 5 Journal of Civil Liberties 30.

24 We have not even mentioned perhaps the greatest human rights violation of them all, resulting from the post-Communist collapse of Russia's once excellent health service: barely one in ten pregnancies result in a normal birth; less than a third of recorded pregnancies produced a live birth in 1999; deaths exceed births on a monthly basis in many large regions; the birth rate has more than halved since 1989; and 30 per cent of all new born Russian babies now die of infections: Goskomstat (the Russian statistical agency), reported in The Times 11 July 2000. 
any local authority, despite the fact that not only are they external to the democracy over which they rule but that they are also the culmination of a legal rather than a political (and therefore an accountable) discourse. In modern democratic theory, this may be understood and justified as "taking rights seriously" 25 but it does raise serious questions about the limitations inherent in the kind of domestic dialogue which the European Court has in mind when it commits itself to democracy.

It is clear that the rights to property, to fair procedures, to privacy and so on set out in the Convention and its protocols circumscribe the national political discourse in most Member States, to a greater or lesser extent, depending on the integrity of its rule of law and the degree of Convention penetration of its legal culture. We see evidence of this every day in the vast number of infringements of the Convention found by the European Court in the hundreds of cases from the Member States that now come before it every year. ${ }^{26}$ The Court does however have both institutional and juristic means available to it to ameliorate the consequences of its (from the democratic perspective) apparently paradoxical actions. At the structural level, the Court has frequently stressed the subsidiary nature of the Convention's regime for the protection of human rights, evident in Article 1's reference to the duties of Member States and Article 13's requirement for effective domestic remedies in relation to human rights breaches. ${ }^{27}$ The Court itself (as noted above) does not oversee the implementation of its own decisions: this falls within the jurisdiction of the relevant national authorities, supervised by the Council's Committee of Ministers. ${ }^{28}$ So while not exactly in a position to contradict the Strasbourg intrusion into its zone of competence, national governments are able to connect such rulings with their own circumstances in ways of their own choosing, subject not to the controlling oversight of the judges but to the political scrutiny of the foreign ministries of the Council's Member States. ${ }^{29}$

At a juristic level, the textual allowance made for exceptions to rights that are "necessary in a democratic society" has been deployed as a means of permitting local authorities to make the initial assessment of how far the language of rights needs to be required to be diluted in the name of representative democracy. Even articles which do not carry this proviso have been construed by the Court in a way which has opened up the

25 The phrase is of course Dworkin's. See his Taking Rights Seriously (1977).

26 A glance at Kempees, A Systematic Guide to the Case-Law of the European Court of Human Rights 1960-96 (three volumes) (1996 and 1998) will persuade the doubters.

27 And see Handyside v United Kingdom (1976) 1 EHRR 737, para 48.

28 See Marckx v Belgium (1979) 2 EHRR 330 at para 58: "the Court's judgment is essentially declaratory and leaves to the State the choice of the means to be utilised in its domestic legal system for performance of its obligations under Article 53".

29 See Execution of Judgments of the European Court of Human Rights, op cit $\mathrm{n}$ 14. This is an underresearched topic, on which see however Tomkins, "Civil Liberties in the Council of Europe: A Critical Survey" in Gearty (ed), European Civil Liberties and the European Convention on Human Rights. A Comparative Study (1997), p 1. 
potential for the balancing of rights and the public interest. ${ }^{30}$ These various chinks in the absolutism of rights-talk have been developed by the Court into a means by which national authorities are accorded a "margin of appreciation" in their application of the Convention. ${ }^{31}$ Though the margin of appreciation has many detractors, ${ }^{32}$ one of its conceptually attractive side-effects from the democratic perspective has been to free the Court to be deferential to public authorities within the Member States even where the facts before the Court have seemed to suggest a breach of the Convention. Implicit in this approach to the margin of appreciation is an acceptance of the inherency of conflict in relation to the resolution of rights arguments, and a recognition that the Strasbourg Court need not always insist on the last word. However, despite its extensive use and its roots in a kind of politico-legal democratic theory, the Court has not developed the concept of the margin of appreciation in a democratically sensitive way. The degree of Strasbourg oversight of local action has depended more on the nature of the conduct involved - the ambit of the right in issue - than on the democratic legitimacy (or otherwise) of the public authority engaged in the limitation of the right. Thus national courts have been shown as much (or as little) deference as the actions of democratically legitimate public authorities ${ }^{33}$ and when direct acts of the legislature have been particularly protected then it has often been as much because of the field under scrutiny - social and economic interests for example - as it has been on account of the decision-making body's democratic credentials. ${ }^{34}$ Where the ambit of the case has been undeniably central to the Convention, the desire to defer to the national legislature has rarely been explicit, with the occasional result of a degree of analytical confusion. ${ }^{35}$ This failure distinctly to locate the margin of appreciation in a coherent theory of representative democracy is a missed opportunity. But at least the Court has been alive, even if sometimes only implicitly, to the oddity of its counter-democratic oversight of "human rights" in the name of "democracy" and has deployed various institutional and juristic devices (albeit imperfectly) to ameliorate the consequences of its own power, thereby rendering less unacceptable its otherwise very peculiar engagement with Europe's properly functioning representative democracies.

${ }^{30}$ For example Article 14. See McHarg, "Reconciling Human Rights and the Public Interest: Conceptual Problems and Doctrinal Uncertainty in the Jurisprudence of the European Court of Human Rights" (1999) 62 MLR 671.

31 Van Dijk and van Hoof, Theory and Practice of the European Convention on Human Rights (3rd ed, 1998), pp 82 - 95 is a good survey of the relevant caselaw. See also Jones, "The Devaluation of Human Rights under the European Convention" [1995] PL 430.

32 See Lavender, "The Problem of the Margin of Appreciation" (1997) 2 EHRLR 380.

33 In an important early case, the Court extended the margin of appreciation to "the domestic legislator . . . and to the bodies, judicial amongst others, that are called upon to interpret and apply the laws in force": Handyside v United Kingdom, op cit $\mathrm{n} 27$, para 48.

34 Cf Marks, op cit n 2, pp 218-21.

35 See for eg James v United Kingdom (1986) 8 EHRR 123 and Lithgow v United Kingdom (1986) 8 EHRR 329 on Article 6.1. For an analysis of the impact of the Court's judgments on selected Member States see Gearty, op cit n 29. 


\section{The Court and the oversight of democratic systems}

Our third and final cautionary note in relation to the European Court's commitment to democracy and human rights flows from what we have just been saying about the Court's relationship with the representative democracies over which it (somewhat ambiguously) presides. When the Court says, as it did in United Communist Party of Turkey (quoted by Mowbray), that it "considers one of the principal characteristics of democracy to be the possibility it offers of resolving a country's problems through dialogue, without recourse to violence, even when they are irksome", ${ }^{36}$ we are immediately confronted with a paradox even deeper than that discussed above concerning the imposition from the outside of judicially defined human rights on Europe's mature democracies. The European Court of Human Rights is not restricted by the Convention and its protocols to the policing of Member States for compliance with its version of substantive human rights. The language of the Convention also requires of the Court's a degree of oversight in respect of each Member State's democratic system; Strasbourg has a textually-based jurisdiction to assess the "democratic" validity of the law-making process itself. Thus Article 3 of the First Protocol guarantees the holding of "free elections at reasonable intervals by secret ballot, under conditions which will ensure the free expression of the opinion of the people in the choice of the legislature". The civil liberties clauses in the Convention, on thought, conscience, speech, assembly and association ${ }^{37}$ can likewise be read, and are read by the Court, as guaranteeing not only substantive human rights as such but also as intended to deliver the kind of political culture in which this right to a free election, and to democracy in general, can be made meaningful. The terms of the Convention itself therefore necessarily involve the Court in checking (when the occasion arises via litigation) that the system under scrutiny is (in the Court's view) truly democratic. This means that in situations judged by the Court to require it, the Court is empowered to interfere with the status quo in a Member State not only on an issue of substantive rights but also where the State is found to have failed the Court's test of what its version of democracy requires. There is irony as well as paradox in this: an unelected judicial body standing outside the democratic dialogue it purports to foster, determining not only what rights should matter but also, a priori in the name of democracy, setting out how such a dialogue should be conducted.

There is an important point of democratic principle here. As William Cobbett wrote, "[ $\mathrm{t}] \mathrm{h}$ e great right of every man, the right of rights, is the right of having a share in the making of the laws, to which the good of the whole makes it his duty to submit." 38 In an important recent book, Jeremy Waldron has recovered this idea of the "right of rights" and has made it the centrepiece of a powerful chapter on the limitations of judicially imposed versions of what a commitment to rights should entail. ${ }^{39}$

36 Op cit $\mathrm{n} 3$ at para 57 quoted by Mowbray op cit $\mathrm{n} 1$ at $\mathrm{p} 706$.

37 Articles 9 - 11.

38 Advice to Young Men and Women, Advice to a Citizen (1829) quoted in McFarlane, The Theory and Practice of Human Rights (1985), p 142.

39 Law and Disagreement (1999), ch 11. 
Waldron's central insight is that even within a discourse that accepts the idea of human rights, the issue of which rights should prevail and in which circumstances is one that will never be fully resolved by argument about rights alone: disagreement is as inherent here as it is elsewhere in every freely-functioning body politic. Thus what is also required in addition to a theory of rights is a "theory of authority" which will serve to "identify some view as the one to prevail on criteria other than those which are the source of the original disagreement". ${ }^{40}$ This theory of authority might even trump rights in which one believes: "[a] person who holds a complete political theory - one that includes a theory of authority as well as theories of justice, rights, and policy - may find himself committed to the view that the wrong decision ought to prevail." ${ }^{41}$ Much depends of course on what exactly one's theory of authority is: if it is that one is always not only right but entitled because of this alone to have one's view prevail over others, then the conflict between authority and right anticipated in the preceding quote would never arise.

It does however arise for Waldron: "When someone asks, "Who shall decide what rights we have?', one answer (my answer) is: 'The people whose rights are in question have the right to participate on equal terms in that decision." "42 But Waldron recognises that this is not the only possible answer: "Instead of empowering the people on the grounds that it is after all their rights that are at stake, we might instead entrust final authority to a scholarly or judicial elite, on the ground that they are more likely to get the matter right." 43 In an influential book the American scholar John Hart Ely developed a framework for legitimate constitutional adjudication rooted in the assumption that what courts were best equipped to do - and what they should therefore without embarrassment do - was to foster the conditions in which a truly democratic discourse (the kind of discourse favoured by Waldron) could take place. ${ }^{44}$ This division of authority into procedural guarantees (the preserve of the courts) and substantive outcomes (the responsibility of the - now guaranteed to be properly democratic - legislature) has been hugely appealing but - as Frank Michelman has recently remarked - it fails to address two vital questions: "Why should it not be left to democratic procedures to decide the standards of democracy and their applications? Why should questions of what counts as 'democratic' be decided extra-democratically, vital as they evidently are to important moral and practical concerns of members of the populace?" 45

To a degree, as we have seen, the European Court of Human Rights has been alive to these conundra. In theory, it is the elite judicial body that tells everyone in Europe which rights should triumph. In practice, the Court frequently defers to judgments about rights emanating from local

$40 \quad$ Ibid $\mathrm{p} 245$.

${ }^{41}$ Ibid $\mathrm{p} 246$

42 Ibid $\mathrm{p} 244$ (italics in original).

43 Ibid.

44 Ely, Democracy and Distrust. A Theory of Judicial Review (1980). See further Sunstein, The Partial Constitution (1993).

45 Michelman, "Human Rights and the Limits of Constitutional Theory" (2000) 13 Ratio Juris 63, at p 64. 
legislatures and courts in Member States not only (or even necessarily) because they agree with the outcomes on rights in such cases but because the Court has chosen to dilute its own authority with a democratically tactful commitment to subsidiarity - perhaps we might even call it partnership. To adopt Waldron's language, there is a shared theory of authority between national authorities and the European Court of Human Rights. This still leaves the question of how the Court exercises its power in relation to its jurisdiction over the democratic health of the decisionmaking processes within Member States which as we have seen the terms of the Convention unequivocally repose in it. Viewed in the abstract, we would expect the sharing of authority with Member States over which rights should triumph in situations of conflict to be predicated (explicitly or implictly) on the assumption that the rival source of authority in the state concerned is democratically constituted. Why else defer to local judgment in so important an area as human rights, particularly when such a heavy emphasis is so frequently placed by the Convention (and the Strasbourg case-law) on the importance of democracy? But as we earlier saw in relation to the margin of appreciation, the Court has not developed its caselaw in the direction of such an explicit, democratically-rooted deference to local judgments. Even if it had, Michelmas's nagging questions would have remained: is it any job of the European Court of Human Rights to tell its Member States what "democracy" means or to override local judgments as to what in specific situations is in the best interests of democracy? The point is particularly relevant when considering the Court's role in relation to western Europe's mature representative democracies; if Michelmas's questions are to be answered in a democratically sensitive way, then we would expect the inclination towards judicial restraint to have taken a very firm grip in this area, and for the Court to have effectively opted out, despite the notional power the Convention gives it, reserving its intrusive fire for newer Member States with less solid grips on democratic principle.

In fact the situation is less principled than might have been expected. Article 3 of the First Protocol certainly has been conservatively applied, with the Strasbourg organs showing themselves to be very wary of telling Member States how to organise their democracies. ${ }^{46}$ Thus the Commission has held inadmissible an application from a Jersey resident that his nonparticipation in Westminster elections was a breach of the Protocol ${ }^{47}$ and it has also rejected attempts to force the UK to adopt a particular system of voting (PR) in its parliamentary elections. ${ }^{48}$ In the first case that came before it on the subject, Mathieu-Mohin and Clerfayt $\mathrm{v}$ Belgium, ${ }^{49}$ the Court declared the Article to be of "prime importance in the Convention system" 50 but recognised that in this sphere Member States enjoyed "a

46 For a survey of the caselaw under this provision see van Dijk and van Hoof, Theory and Practice of the European Convention on Human Rights, op cit $\mathrm{n}$ 31 , at pp. 655-66. Marks, op cit n 2, at pp 221-28 is also excellent.

$47 X$ v United Kingdom (1982) 28 DR 99

$48 X \mathrm{v}$ United Kingdom (1977) 7 DR 95. See also Liberal Party, Mrs $R$ and MrP v United Kingdom (1981) 21 DR 211.

49 (1987) 10 EHRR 1.

50 Ibid para 47. 
wide margin of appreciation". ${ }^{51}$ The Court considered that for the purposes of this Article, any electoral system had to "be assessed in the light of the political evolution of the country concerned" with "features that would be unacceptable in the context of one system" capable of being "justified in the context of another, at least so long as the chosen system provides for conditions which will ensure the 'free expression of the opinion of the people in the choice of the legislature. "“52 Similar dicta are to be found in Matthews v United Kingdom, though on the very particular facts of that case (the right of persons in Gibraltar to vote in European elections), the Court did find a breach of the Article. ${ }^{53}$

In contrast to Article 3 of the First Protocol, however, the Strasbourg judges have developed an extensive jurisprudence under Article 10 (and to a lesser extent Article 11) which has enabled them to be vigilant in countering efforts by national authorities to stifle political debate in what they have judged to be illegitimate ways. To a degree of course this can be understood as an entirely different issue from that dealt with in Article 3; overseeing the impact of a State's democratic system on political freedom in particular cases is very different from scrutinising the internal workings of the system itself. In any event, far from applying a wide margin of appreciation, European supervision here has been much closer and more unrelenting than in other areas. ${ }^{54}$ In the context of political speech and Article 10, the margin of appreciation has been narrowly construed, with the Strasbourg organs having been vigilant in their protection of the right. In exerting this control the Court has not paid too much attention to which domestic branch of government has been responsible for the alleged infringement. ${ }^{55}$ Under this head of review therefore the Court has scrutinised executive acts, ${ }^{56}$ a State's criminal $\operatorname{code}^{57}$ and its judge-made law. ${ }^{58}$ Nor has this approach been controversial; indeed there has been widespread support for the case-law which has asserted the principle of political speech over domestic law even where these laws have emanated directly or indirectly from the national

51 Ibid paras 52 and 54. But $c f$ the joint dissenting opinion of Judges Cremona, Bindschedler-Robert, Bernhardt, Spielmann and Valticos (at ibid.p 21): "Falling back on the margin of appreciation is no answer in this case, because that margin is subject to effective respect for the rights protected in the Convention."

52 Ibid para 54.

53 (1999) 28 EHRR 361. See comments on the margin of appreciation at para 63 of the Judgment. And see further Ahmed v United Kingdom (1998) 29 EHRR 1 , at paras 72-6 of the Judgment.

54 Leading cases include Lingens v Austria (1987) 8 EHRR 407 and Castells v Spain (1992) 14 EHRR 445

55 A different kind of democratic issue is raised if the invasion of speech is the result of a constitutional amendment upon which the people of a State have recently voted: see Open Door Counselling and Dublin Well Woman v Ireland (1992) 15 EHRR 244, especially the dissenting opinion of Judge Cremona at $p$ 271 and of Judges Pettiti, Russo and Lopes Rocha at pp 275-6.

56 Steel and others v United Kingdom (1998) 28 EHRR 603.

57 As in Lingens, op cit $\mathrm{n}$ 54; Castells v Spain, op cit $\mathrm{n} 54$.

58 Observer and Guardian v United Kingdom (1991) 14 EHRR 153; Sunday Times v United Kingdom (No. 2) (1991) 14 EHRR 229. 
legislature. When a couple of controversial cases from the United Kingdom in the late 1980s and early 1990s involving political speech and association rights were found to be inadmissible by the Commission, the decisions were much criticised precisely because a more intrusive oversight from Strasbourg on such vital political issues had been expected, notwithstanding that in both cases the legislature had voted to support the relevant executive action (albeit in each case after the event). ${ }^{59}$

What we have from the European Court of Human Rights (and before it the Commission) therefore is a strongly contrasting approach to Strasbourg's power to oversee the democratic health of Member States. On the one hand, the Strasbourg authorities have been very deferential where the particular system of representative democracy chosen by the Member States has been explicitly before it in the form of an application engaging Article 3 of the First Protocol. On the other hand, the Court and Commission have been vigilant, indeed confidently intrusive, so far as the protection of political speech has been concerned, and have been activist even where this has involved assertions of power over domestic criminal codes and national legislation. The distinction between these two kinds of judicial engagement, the one passive, the other invasive, is however to some extent a false one. In particular, a Member State may choose to arrange its constitutional affairs so as to limit certain kinds of political speech, not with the primary intention of suppressing opinion (as in the Article 10 cases discussed above) but in order to facilitate a level of political debate which the State views as vital to the health of its representative democracy. In such circumstances we are confronted with an apparent control on speech which is in fact designed - at a more general, structural level - to achieve the opposite: greater speech, more open political dialogue and a more effective form of democracy. All that we have said about the margin of appreciation and the Court's sensitivity to the sharing of its authority with Member States would suggest a restrained judicial approach, with the Member State being permitted to make its own assessment of what exactly suits its local democratic circumstances and then to act on that assessment. Instead, mislead by a false analogy with the Article 10 cases discussed above, the Court has recently intervened aggressively in just such a situation, in Bowman $v$ United Kingdom. ${ }^{60}$

The case involved a challenge to the United Kingdom's electoral laws, under which rigorous controls were placed on the amount of money that could be spent by election candidates during their parliamentary campaigns. As part of this statutory scheme, designed to "safeguard the position of candidates without access to substantial resources," 61 the legislation also prohibited any expenditure of more than $£ 5$ by any third party "with a view to promoting or procuring the election of a candidate". ${ }^{62}$ It was under this provision that the applicant - a well-known

59 Council of Civil Service Unions and others v United Kingdom (1987) 10 EHRR 269; Brind v United Kingdom (1994) 18 EHRR CD 76.

60 (1998) 26 EHRR 1.

61 Ibid para 18.

62 Representation of the People Act 1983, s 75(1). 
campaigner against abortion and executive director of the Society for the Protection of the Unborn Child - was charged. Her alleged offence had been to circulate 25,000 leaflets in a particular constituency identifying how each candidate there was likely to vote on the abortion issue if elected to Parliament. (One and a half million similar such leaflets were distributed nationwide.) The prosecution was unsuccessful, despite which the applicant managed to get to Strasbourg as a "victim" of an alleged infringement of her free speech rights under Article 10. Before the Commission, the Government explained the necessity of the funding controls as a means of ensuring "the right of each individual candidate to stand on equal terms with his or her rivals" which would be rendered "pointless if other persons were allowed to incur expenses on their behalf" the effect of which would be to "put at an advantage those candidates who had wealthy supporters or the support of particular pressure or campaign groups". ${ }^{63}$ The controls did not prevent such persons putting their points of view at any other times, and indeed even during the campaign itself as long as the expression in issue did not fall within section $75: 64$ " $[\mathrm{t}] \mathrm{he}$ limitation imposed by section 75 relate[d] only to the promotion of candidates, not to the promotion of causes". ${ }^{65}$ Despite these arguments, the Commission favoured the applicant by no fewer than 28 votes to one. Freedom of expression was "one of the essential foundations of a democratic society: exceptions to it must be narrowly interpreted and the necessity for any restrictions convincingly established". ${ }^{66}$ Though the State had a "certain margin of appreciation," 67 it was not wide enough to come to the rescue here: the statutory prohibition was too widely construed; the communication of the applicant's information would not necessarily affect the equality of the electoral playing field for the candidates affected; and the fear that single issue campaigning would distort the result had not been made out. "[I]ndividual freedom of expression, as a key ingredient of a democratic society, must be considered inextricably linked with a free election system and cannot be excluded without convincing justification" 68 - which was absent here.

In its very short judgment, the European Court took broadly the same line, albeit by a narrower majority (14 votes to six). It is true that the Court explicitly recognised that section 75 was "only one of the many detailed checks and balances which made up UK electoral law"69 and that States were entitled in the exercise of their margin of appreciation "in the period preceding or during an election, to place certain restrictions, of a type which would not usually be acceptable, on freedom of expression, in order to secure the 'free expression of the opinion of the people in the choice of the legislature. " "70 However the majority nevertheless judged that the UK

63 Op cit $\mathrm{n} 60$, para 42 of the Commission Opinion.

${ }^{64}$ Ibid para 43.

${ }^{65}$ Ibid joint partly dissenting opinion of Judges Loizou, Baka and Jambrek in the Court, para 3

66 Ibid. para 45 of the Commission Opinion.

67 Ibid.

68 Ibid para 46.

69 Ibid para 41 of the Judgment.

70 Ibid para 43. 
had in this case overstepped the mark, for various reasons. First, the $£ 5$ limit was very low. Second, the restriction during the election period deprived the applicant of her power of communication "during the critical period when [the electors'] minds were focused on their choice of representative" 71 Third, the majority was "not satisfied that, in practice, [the applicant] had access to any other effective channels of communication": ${ }^{72}$ in particular while she could herself have stood for election this was not what she wanted to do and she would in all probability have forfeited her $£ 500$ deposit. ${ }^{73}$ Fourthly, while section 75 operated "for all practical purposes, as a total barrier" to the applicant's publishing of information, "there were no restrictions placed upon the freedom of the press to support or oppose the election of any particular candidate or upon political parties and their supporters to advertise at national or regional level, provided that such advertisements were not intended to promote or prejudice the electioral prospects of any particular candidate in any particular constitutency." 74

This reasoning can be criticised in a number of ways. Why should the limit of $£ 5$ be thought too low if the purpose of the restriction - the promotion of fairness between competing candidates - was truly accepted as legitimate? ${ }^{75}$ The whole point of the restriction was that it was during "the critical period": this was not so much a weakness as its central rationale. In a system of representative democracy, it should surely have mattered more than it did to the Court that the applicant was not disabled from herself standing for election, with or without colleagues doing the same in other constituencies, and it should also surely also have mattered that by doing so she would have been able to liberate herself completely from the restriction on her powers of communication that she found so obnoxious. For the Court to mention as relevant that the applicant would almost certainly have lost her deposit might almost be thought an eccentric intervention in a case in which the issue revolved around how vast a sum of money the applicant should be entitled to pour into vicarious election campaigning. When the Court drew attention to the comparative freedom of the press to report as an argument against the restriction before it, it was effectively punishing the United Kingdom for having imposed as narrow a ban as it could consistently with its broader public interest goals. In the language of Strasbourg, it had been too "proportionate" when it would have been safer to have been wildly disproportionate, but it is surely clear what the Court would have said had such an approach being taken. So why mention the freedom of the press in this context at all?

Bowman is a depressing decision because of the majority judges' apparent failure to recognise the debilitating effect of disportionate financial resources on the electoral process. True, the Court does pay lip service to the requirements of political equality, but its emphasis on individual

71 Ibid para 45

72 Ibid para 46

73 Ibid.

74 Ibid para 47 (footnote omitted).

75 A point made by Judge Sir John Freeland in his dissent, paras 9-10 (joined by Judge Levits). 
freedom of expression showed clearly where its priorities lay. The decision is also depressing at a deeper level, of direct relevance to the themes that have been explored in this essay. In the majority decisions of neither the Commission nor the Court is there any mention made of the kind of national law that is being challenged under Article 10. Yet what was in issue here was a piece of primary legislation, of relatively recent origin, ${ }^{76}$ which was specifically designed to provide the conditions for an effective and fair democratic political system for the United Kingdom. ${ }^{77}$ As such the legislation should have been doubly protected in Strasbourg: it was an expression of will by the primary democratic body in the State on an issue - the organisation of that State's democracy - to which the Strasbourg organs had traditionally taken a light touch. ${ }^{78}$ As Sir John Freeland put it in the course of his dissenting opinion on the point, there was "a clear need for a particularly cautious approach to be adopted in adjudicating internationally on rules prescribed by long-established democratic parliaments on matters so intimately involved with their own composition and operation." ${ }^{\prime 79}$ Instead like the proverbial bull in the china shop, the majority's subservience to the demands of a very particular kind of commitment to free speech had the consequence of scattering the careful construction that lay in its path, forcing legislators and other public authorities to pick up the pieces left in its wake. The regulation of election funding is one of the most controversial and politically sensitive issues in the United Kingdom, "a perennial topic of debate" 80 in Britain. Now those seeking to legislate in the field have to take into account a new and uncertain dimension, the effect of which will be to predetermine part of the public debate in a highly individualist and partisan way.

\section{CONCLUSION}

Ill-advised though the decision in Bowman may be, the simple fact of its having been made requires now that it be implemented. Once an applicant leaps through the Court's own self-denying ordinances to secure

76 Though preceding versions of the provision had been on the statute book for very much longer: see for eg Representation of the People Act 1949, s 63.

$77 C f$ in this regard Ahmed v United Kingdom, op cit $\mathrm{n} 53$ where what was in issue were government regulations restricting the political activities of local government officers in certain posts. In finding no violation of either Article 10 or Article 11, the Court placed great reliance on a report into local government which had recommended the promulgation of such regulations: see paras 57-65. Also relevant to the Court was the fact that the new UK administration had conducted a review of the need for these regulations and had found them to be justified: para 63. The Bowman decision is not referred to in any of the judgments in the case.

78 See the comments of the sole dissenting Commissioner Mr F. Martinez at ibid p 14 and (on the Court) the partly dissenting Opinion of Judge Freeland (joined by Judge Levits) and the joint partly dissenting opinion of Judges Loizou, Baka and Jambrek. To another dissentient Judge Valticos should perhaps be left the last word on this point: "There is something slightly ridiculous in seeking to give the British Government lessons in how to hold elections and run a democracy": ibid p 22.

79 Ibid para 12

${ }^{80}$ Ibid para 4, per Sir John Freeland. 


\section{Northern Ireland Legal Quarterly [Vol. 51, No. 3]}

a finding of a violation, the respondent Government is obliged to apply the decision within its jurisdiction, whatever might be its views, or the public's views, as to its merits. Here we have an example of Waldron's theory of authority in action: the decision may be wrong, but that does not mean that it need not be obeyed. In recent years however a degree of unease has emerged over the kinds of decisions that Member States are being asked to implement. As the overseeing body, the Committee of Ministers has been drawn into this emerging debate as has the Parliamentary Assembly of the Council of Europe. ${ }^{81}$ The United Kingdom Government's response to Bowman has been made part of its more general review of campaign funding law. ${ }^{82}$ More controversially an equally recent decision of the Court's, Osman $v$ United Kingdom, ${ }^{83}$ resulted in a decision not to make certain legal arguments before the domestic courts, a mode of compliance that may well suit Strasbourg but which appears not to have been well received in the national courts. ${ }^{84}$ The Court's management of its relations with domestic national authorities is always at risk of being disrupted by judgments perceived domestically as overly intrusive, whether because the margin of appreciation is not applied or because a widely supported piece of primary legislation is called in issue or (as in Bowman) both. Of course there will be many occasions where in the individual case the Strasbourg judgment may not be well received locally despite which it remains right, in the sense of facilitating the protection of human dignity or the promotion of local democracy. One of the purposes of this essay is however to show that, despite the absolutist language of human rights, this is neither inevitably nor invariably the case. Strasbourg decisions can on occasion be as wrong as misguided political acts, and just like the latter they can be very difficult to reverse.

A second conclusion that flows from this essay is that a greater sense of proportion is needed when the activities of the Council of Europe are considered by lawyers. For too long, the focus has been almost exclusively upon the Convention on Human Rights and its enforcement organs, the Court and (until 1998) the Commission at Strasbourg. It is natural that human rights lawyers should be attracted to a body which so obviously speaks their language and behaves in such a lawyerly way, hearing argument and delivering judgment between two parties locked in adversarial combat. But in terms of the protection of human rights across Europe, the Court's role is as only one of a number of bodies active in the pursuit of better human rights protection within the framework of the Council of Europe. The Human Rights Commissioner, the Committee of Ministers and the Parliamentary Assembly of the Council with its political and legal affairs and human rights committees all engage in valuable

81 See Execution of Judgmentsof the European Court of Human Rights, op cit $\mathrm{n}$ 14.

82 See The Funding of Political Parties in the United Kingdom (Cm 4413, 1999), esp at paras 7.2 and 7.36.

83 (1998) 29 EHRR 245.

84 Resolution DH (99) 720, 3 December 1999. See English, "The law lords are already fighting Strasbourg over the Human Rights Act" The Times 29 June 2000 . 
work. So too does the Congress of Local and Regional Authorities of Europe. The Council's Social Charter ${ }^{85}$ its Convention for the Prevention of Torture and Inhuman or Degrading Treatment or Punishment ${ }^{86}$ and its Framework Convention for the Protection of National Minorities ${ }^{87}$ all contribute greatly to the protection of human rights in Europe. The subject is a complex one, requiring action on all fronts, but particularly on the political, where the feelings of anger and hate that breed the worst of our European human rights violations can be directly tackled. The energy required to secure the protection of human dignity across Europe should not be needlessly channelled into any single activity, least of all one rooted merely in litigation.

85 ETS No 35 (18 October 1961), as amended.

86 ETS No 126 (26 November 1987).

87 For the state of signatures and ratifications at 29 February 2000 see (2000) 48 Human Rights Information Bulletin 38. 